\title{
Meiofauna communities in exposed sandy beaches on the Galician coast (NW Spain), six months after the Prestige oil spill: the role of polycyclic aromatic hydrocarbons (PAHs)
}

\author{
PURI VEIGA $^{1}$, CELIA BESTEIRO ${ }^{1,2}$ and MARCOS RUBAL ${ }^{1,3}$ \\ ${ }^{1}$ Departamento de Zooloxía e Antropoloxía Física, Facultade de Veterinaria, Universidade de Santiago de Compostela, \\ Avd. Carballo Calero s/n, 27002, Lugo, Spain. \\ ${ }^{2}$ Estación de Bioloxía Mariña da Graña (EBMG), Casa do Hórreo, Rúa da Ribeira, 1. 15590 A Graña, Ferrol, Spain. \\ ${ }^{3}$ Present address: CIIMAR/CIMAR-LA, Centro Interdisciplinar de Investigação Marinha e Ambiental, \\ Universidade do Porto, Laboratório de Biodiversidade Costeira, Rua dos Bragas, 289, 4050-123 Porto, Portugal. \\ E-mail: mrubal@ciimar.up.pt
}

SUMMARY: The effect of polycyclic aromatic hydrocarbons (PAHs) on Galician sandy beach ecosystems, six months after the Prestige oil spill, was evaluated using the meiobenthos at a higher taxon level as an indicator. Meiobenthos community structure, environmental variables and sediment PAH content from six affected exposed beaches were studied and compared with three reference sites. They were also compared with data from polluted beaches obtained during the first days of the spill. Significant amounts of PAHs were found in affected beach sediments and both univariate and multivariate analyses showed differences between affected and reference beaches. Correlation analyses between PAH content and the meiobenthos community structure showed that 1,2-dimethylnaphthalene (C2-NAPH) and 1-methylphenanthrene (C-PHEN) affected both the community structure and the abundance of the main taxa. These two PAHs seem to be responsible for the low meiofauna density values, which suggests that there is a relationship between the oil spill and the differences between affected and reference localities.

Keywords: oil spill, Prestige, beach, meiobenthos, 1,2-dimethylnaphthalene, 1-methylphenanthrene, multivariate analysis.

RESUMEN: LAS COMUNIDADES MEIOBENTÓNICAS EN PLAYAS ARENOSAS EXPUESTAS DE LA COSTA GALLEGa (NO ESPAÑA), SEIS MESES DESPUÉS DEL VERTIDO DE FUEL DEL PRESTIGE: IMPORTANCIA DE LOS HIDROCARBUROS AROMÁTICOS POLIĆ́ĆCICOS (HAPs). - Este trabajo tiene como objetivo evaluar el efecto de los hidrocarburos aromáticos policíclicos (HAPs) en playas arenosas gallegas, seis meses después del vertido de fuel producido por el Prestige, utilizando el meiobentos a nivel de los grandes grupos zoológicos. Para llevar a cabo esta evaluación la comunidad meiobentónica, variables ambientales y el contenido en HAPs del sedimento fueron estudiados en seis playas intermareales afectadas y comparados con tres localidades de referencia. También fueron comparados con datos de playas contaminadas obtenidos durante los primeros días del derrame. Considerables cantidades de HAPs fueron encontradas en los sedimentos de las playas afectadas y tanto los análisis univariantes como los multivariantes indicaron diferencias entre las playas afectadas y las de referencia. Los análisis de correlación entre el contenido en HAPs y la estructura de la comunidad meiobentónica indicaron que el 1, 2-dimetilnaftaleno (C2-NAPH) y el 1-metilfenantreno (C-PHEN) jugaban un papel importante tanto en la estructura de la comunidad como en la abundancia de los principales taxones. Estos dos HAPs parecieron ser los responsables de las bajas densidades de meiofauna, corroborando la relación entre el vertido de fuel y las diferencias entre las localidades afectadas y de referencia.

Palabras clave: vertido de fuel, Prestige, playas, meiobentos, 1, 2-dimetilnaftaleno, 1-metilfenantreno, análisis multivariante. 


\section{INTRODUCTION}

Biogenic and petrogenic hydrocarbons are the result of the slow decay of the animals and algae from plankton, so they must be considered part of the marine environment (Kingston, 2002). However, Suchanek (1993) estimated that only $8 \%$ of the annual oil input to the oceans is derived from these natural sources. The same author noted that the main anthropogenic sources of oil in the ocean were: runoff and municipal and industrial wastes (36\%), oil released during tanker operational discharges $(22 \%)$ and accidental or deliberate tanker spills (12\%). Even if oil spills are not the main source of hydrocarbons in coastal areas, they attract high-profile coverage in the news media, and their effects on ecosystems have been widely studied, especially in intertidal areas (e.g. Wormald, 1976; Ansari and Ingole, 2002). After the Amoco Cadiz oil spill Bodin (1988) documented two different phases at 3 intertidal beaches on the French Atlantic coast. The first phase corresponds to an acute toxicity with severe reduction in density and diversity of the main meiofauna taxa, followed by a recovery phase at the end of which these taxa reach density and diversity values similar to those before the spill.

After an oil spill the amount of oil that reaches the coast decreases with time due to natural degradation processes such as photolysis, dilution, evaporation and biodegradation. Oil is a complex mixture of substances, of which polycyclic aromatic hydrocarbons (PAHs) have proved to be most responsible for the negative effects on animals, due to their carcinogenic, mutagenic and toxic effects (Lotufo and Fleeger, 1997). Therefore, the remaining concentration of PAHs in the sediment, after an oil spill, plays a central role in the impact and recovery process of benthic environments.

In intertidal environments meiofauna is a diverse and conspicuous component of the benthic fauna, and on exposed beaches its abundance and diversity is higher than that of macrofauna (Brown and McLachlan, 1990). However, most meiofauna species spend their whole life cycle in the sediment, respond quickly to pollution events, and sublethal effects on fecundity or growth can be detected at community level due to their fast generation time (Moore and Bett, 1989). All these features make meiofauna more efficient than macrofauna as pollution indicators (Fleeger and Chandler, 1983). However, difficulties in the taxonomic work increase with decreas- ing animal size, which is the major disadvantage of meiofauna as pollution indicators (Moore and Bett, 1989). In order to solve this problem Ellis (1985) proposed the Taxonomic Sufficiency (TS) principle. The TS principle states that community components should be identified at the level that provides the required information for the purpose of the work. This principle has been applied successfully to the meiofauna in many pollution studies (e.g. Herman and Heip, 1988).

The Galician Atlantic coast (NW Spain) has suffered three of the world's largest oil spills in the last 30 years, due to the wreckages of the Monte Urquiola, Aegean Sea and Prestige. In November 2002, the Prestige tanker spilled 50000 tons of heavy fuel oil (M-100), in successive black tides. After the spill several authors studied the effect of the black tide on sublittoral and intertidal benthic communities (Junoy et al., 2005; Rodríguez et al., 2007; Veiga et al,. 2007; 2009). The aims of this work are to evaluate the effect of PAHs on sandy beaches, 6 months after the Prestige oil spill, using meiobenthos at a higher taxon level of aggregation. For this, the meiofaunal community, environmental variables and $\mathrm{PAH}$ sediment concentration at 6 exposed sandy beaches along the Galician coast were studied. Community structure and the abundance of the main meiobenthic taxa from these 6 beaches were compared with 3 reference beaches and with data from polluted beaches obtained during the acute toxicity phase in the first days of the spill. Relationships between PAH concentration, environmental variables, community structure and the abundance of the main meiobenthic taxa were also studied in order to identify the impact of individual PAHs on the meiobenthic community structure.

\section{MATERIALS AND METHODS}

\section{Sampling and sample processing}

Nine beaches were studied along the Galician coast (Fig. 1). Three of them were sampled from 26 April to 26 May 2002, six months before the Prestige oil spill, and are considered as references. Altar (REF A) is an exposed beach situated in the outer part of the Ría de Foz; while the other two reference localities are exposed beaches located at the Ría de O Barqueiro: Xilloi (REF B) and Vidrieiro (REF C). The other beaches were sampled from 6 April 


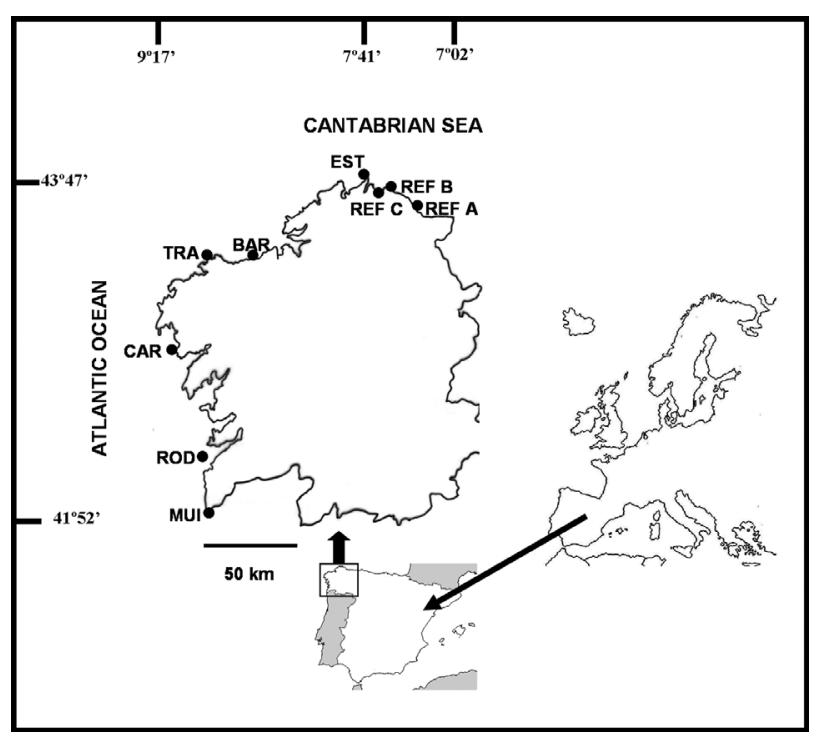

FIG. 1. - Study area and sampling locations. Each location is indicated by a full dot and different letter combinations. REF A: Altar, REF B: Xilloi, REF C: Vidrieiro, EST: Esteiro, BAR: Barrañán, TRA: Traba, CAR: Carnota, ROD: Rodas and MUI: Muíños.

to 18 May 2003, six months after the Prestige oil spill, and were affected to different degrees by the spill (Junoy et al., 2005; Rodríguez et al., 2007). At smaller beaches (less than $1.3 \mathrm{~km}$ in length), REF A, REF B, REF C, Esteiro (EST), Barrañán (BAR) and Muíños (MUI), one site was studied, while at larger beaches (more than $1.3 \mathrm{~km}$ ), Traba (TRA1; TRA2), Carnota (CAR1; CAR2) and Rodas (ROD1; ROD2), two sites were studied.

During the sampling period, intense cleaning operations were being performed. Cleaning operations have been proven to have similar or larger effects than the actual oil spills on benthic fauna (Whitfield, 2003). In order to avoid the confounding effect of cleaning activities only the swash zone, where cleaning intensity was low or absent, was considered in this work. Both at reference and affected beaches, three cores $10 \mathrm{~cm}$ long with an inner diameter of $3.6 \mathrm{~cm}$ (sampling surface $10 \mathrm{~cm}^{2}$ ), were collected for the meiobenthos study at each site. Moreover, at each affected location three cores were collected for the granulometry analysis. Cores were pooled in a previously weighed plastic container for the study of sediment water content $(\mathrm{Wc})$ and mean grain size $(\mathrm{Md})$. Sediment temperature $(\mathrm{T})$ was measured in situ by a multi-parametric probe and beach slope and Dean's parameter values were calculated. Dean's parameter describes the beach morphodynamic state as: $\Omega=\mathrm{Hb} / \mathrm{W} \mathrm{T}$, where $\mathrm{Hb}$ is the breaker height, $\mathrm{T}$ the wave period and $\mathrm{W}$ the fall velocity of the sand. To study the sediment polycyclic aromatic hydrocar- bon (PAH) content at affected beaches three more cores were collected at each locality; these cores were pooled in a previously decontaminated bag and stored in the dark at $-20^{\circ} \mathrm{C}$ until their analysis. For reference localities environmental data were obtained from Rubal (2008) and Veiga (2008).

Meiofauna samples were processed immediately after collection. They were treated with a $7 \% \mathrm{MgCl}_{2}$ solution for 10 minutes for the narcotization of the fauna, and preserved in 10\% neutralized formaldehyde solution with Rose Bengal. The meiofauna was extracted by decantation through a $30 \mu \mathrm{m}$ mesh size sieve (Pfannkuche and Thiel, 1988). This procedure was repeated six times for each sample. All meiobenthic organisms were counted and identified to the higher taxa under a stereomicroscope. Sediment samples were dried at the laboratory at $60^{\circ} \mathrm{C}$ for 72 hours to calculate the sediment Wc. From these samples the Md was calculated following the procedures described by Buchanan (1984). Analyses of PAHs were carried out by the General Services to Research (SXAIN) at the A Coruña University (Spain). Samples for PAH analyses were dried in previously decontaminated glass containers in darkness. PAHs were extracted from the dried samples and analyzed by gas chromatography and mass spectrometry. Forty parent PAHs, including the 14 parental PAHs, were considered until a detection level of $0.1 \mathrm{ppb}$.

\section{Data analyses}

In order to evaluate the state of the meiobenthic community at impacted beaches six months after the Prestige spill, the density of the main meiobenthic taxa and the meiobenthic community structure of affected beaches were compared to reference beaches.

Densities of the most abundant groups, total meiofauna and number of taxa at impacted and reference beaches are presented as means $( \pm$ SD). Significant differences between sites were studied with a one-way analysis of variance (one-way ANOVA), followed by a Tukey honestly significant difference (HSD) multiple-comparison test, whenever applicable. Site was the random factor and density of the main meiobenthic taxa the variable. Prior to the analysis, the normality of the data was checked with a Kolgomorov-Smirnov normality test and variance homogeneity with a Cochran test. These analyses were performed with the STATISTICA 6.0. package. 
TABLE 1. - Environmental parameters: Dean's parameter, beach slope, median particle diameter in micrometres (Md), sediment water content in percentages (Wc) and sediment temperature in degrees Celsius $(\mathrm{T})$.

\begin{tabular}{|c|c|c|c|c|c|c|c|c|}
\hline \multirow{2}{*}{$\begin{array}{l}\text { Beach } \\
\text { EST }\end{array}$} & \multirow{2}{*}{$\begin{array}{c}\text { Date } \\
16 / 04 / 03\end{array}$} & \multicolumn{2}{|c|}{ Location } & \multirow{2}{*}{$\frac{\text { Dean }}{2.0}$} & \multirow{2}{*}{$\begin{array}{c}\text { Slope } \\
0.04\end{array}$} & \multirow{2}{*}{$\frac{\mathrm{Md}}{350}$} & \multirow{2}{*}{$\begin{array}{l}\mathrm{Wc} \\
19.6\end{array}$} & \multirow{2}{*}{$\frac{\mathrm{T}}{12.0}$} \\
\hline & & $43^{\circ} 43^{\prime} \mathrm{N}$ & $7^{\circ} 34^{\prime} \mathrm{W}$ & & & & & \\
\hline BAR & $18 / 04 / 03$ & $43^{\circ} 18^{\prime} \mathrm{N}$ & $8^{\circ} 32^{\prime} \mathrm{W}$ & 1.3 & 0.05 & 572 & 23.1 & 15.9 \\
\hline TRA & $17 / 04 / 03$ & $43^{\circ} 11^{\prime} \mathrm{N}$ & $9^{\circ} 09^{\prime} \mathrm{W}$ & 1.2 & 0.10 & 508 & 22.7 & 14.9 \\
\hline CAR & $17 / 05 / 03$ & $42^{\circ} 49^{\prime} \mathrm{N}$ & $9^{\circ} 07^{\prime} \mathrm{W}$ & 4.0 & 0.06 & 391 & 24.7 & 14.5 \\
\hline ROD & $18 / 05 / 03$ & $42^{\circ} 11^{\prime} \mathrm{N}$ & $8^{\circ} 52^{\prime} \mathrm{W}$ & 0.4 & 0.12 & 1007 & 16.7 & 15.0 \\
\hline MUI & $16 / 05 / 03$ & $41^{\circ} 52^{\prime} \mathrm{N}$ & $8^{\circ} 51^{\prime} \mathrm{W}$ & 0.2 & 0.17 & 1079 & 21.4 & 17.0 \\
\hline
\end{tabular}

The multivariate study of the community was performed using the statistical package PRIMER 6.0. The replicate meiofauna abundance data of each site were square root transformed for calculating the Bray-Curtis similarity matrix. The relationship between meiobenthic communities of the sampled localities (reference and affected) was displayed using non-metric multidimensional scaling (MDS).

The relationships between the meiobenthic assemblage structure of impacted beaches with environmental variables and sediment $\mathrm{PAH}$ content were examined using the BIOENV procedure as an exploratory method (Clarke and Ainsworth, 1993). Due to the large number of different PAHs measured a BVSTEP analysis was performed to identify significant PAHs previously to the BIOENV analysis. These two analyses find the best match between the patterns of community structure and the environmental variables associated with them. BIOENV carries out a full search of all possible combinations of variables, while BVSTEP carries out a stepwise procedure to arrive at an optimal set of variables when there are too many variables. Prior to the analyses, all the environmental data were normalized and transformed when needed. The statistical significance of the BIOENV and BVSTEP analyses were tested by a permutation test (999 permutations).

Once the main PAHs and environmental variables were identified by the BIOENV procedures, their importance in determining the density of the major meiobenthic taxa was studied. For this aim the hierarchical partitioning analysis $(\mathrm{Hp})$ was performed. Hp compares all possible models in a multiple regression setting and determines the independent capacities of the predictive variables (PAHs and environmental variables) to explain the variability patterns in the corresponding response variable (density of the main taxa). The independent explanatory power of each predictor on the dependent variable is characterized by an index "I", which reflects the independent contribution of the predictor to the variance explained by the models. Variables that explained a larger proportion of variance than by chance, were identified using randomization tests. For each predictor, the observed contribution to the explained variance (I) was compared to the distribution of a population of Is of 999 randomizations of the data matrix. Significance was accepted at the upper $95 \%$ confidence limit ( $\mathrm{Z}$ score $\geq 1.65$ ). Hierarchical partitioning procedures were estimated using the hierarchical partitioning software for the public domain package R (Walsh and Mac Nally, 2003). The hierarchical partition approach alleviates one of the major limitations of multiple regressions, namely that the contributions of each predictor variable are dependent upon which other predictor variables happen to be included in the model (Mac Nally, 2000). This procedure was recently successfully used in benthic ecological (Arenas et al., 2006) and in water quality management studies (Walsh et al., 2004).

\section{RESULTS}

\section{Environmental parameters}

The main environmental characteristics of the affected localities are reported in Table 1. Values of Dean's parameter and slopes showed that the morphodynamic state of the studied beaches were intermediate between reflective and dissipative, except for ROD and MUI that were reflective, reaching the highest slope values. Md varied from $350 \mu \mathrm{m}$ up to $1079 \mu \mathrm{m}$, showing that sediments were medium sands at EST and CAR, coarse sands at BAR and TRA and very coarse sands at ROD and MUI. Sediment temperature and water content were quite similar at all the studied sites, with values ranging from $12^{\circ} \mathrm{C}$ to $17^{\circ} \mathrm{C}$ and from $16.7 \%$ to $24.7 \%$ respectively. The reference localities REF A and REF B are intermediate beaches of medium sands with $\mathrm{Md}$ 
TABLE 2. - Concentrations of sediment PAHs (ppb). Only PAHs with values over the ERL or ERM and those that were correlated with the meiobenthic community structure are shown. Values above the ERL are expressed in bold numbers and values above the ERM are expressed in bold italic numbers.

\begin{tabular}{|c|c|c|c|c|c|c|}
\hline PAHs & EST & BAR & TRA & CAR & ROD & MUI \\
\hline 1,2-Dimethylnaphthalene & 1221.9 & 411.7 & 740.3 & 600.5 & 3257.3 & 12992.5 \\
\hline 1-Methylphenanthrene & 6.2 & 5.7 & 2.7 & 2.9 & 82.3 & 81.2 \\
\hline Naphthalene & 340.4 & 29.3 & 60.8 & 126.1 & 394.7 & 1600.2 \\
\hline Acenaphthylene & 325.5 & 119.0 & 194.3 & 257.2 & 834.1 & 3495.5 \\
\hline Acenaphthene & 75.4 & 31.6 & 29.3 & 89.0 & 264.7 & 942.7 \\
\hline Fluorene & 89.3 & 33.4 & 50.8 & 66.7 & 202.2 & 585.2 \\
\hline Phenanthrene & 193.9 & 88.9 & 121.4 & 153.3 & 364.4 & 1577.8 \\
\hline Anthracene & 32.2 & 7.0 & 14.3 & 19.9 & 47.6 & 252.8 \\
\hline Fluoranthene & 86.5 & 28.6 & 41.3 & 48.5 & 115.2 & 615.7 \\
\hline$\sum$ PAHs & 1143.2 & 337.8 & 512.2 & 760.7 & 2222.9 & 9069.9 \\
\hline
\end{tabular}

of $324 \mu \mathrm{m}$ and $314 \mu \mathrm{m}$ respectively, while REF C is a reflective beach of coarse sand with an Md of 637 $\mu \mathrm{m}$ (Rubal, 2008; Veiga, 2008).

Twenty nine PAHs showed sediment concentrations above the detection limit, including almost all the 16 parental PAHs. Seven of these and the $\sum$ PAHs, had values above the effects range-low (ERL) proposed by Long et al. (1995) in at least one locality (Table 2). Four of the previous PAHs were found in concentrations above the effects rangemedium (ERM) proposed by Long et al. (1995) in at least one locality (Table 2). The ERL and ERM values defined concentration ranges that are rarely associated with adverse effects (below the ERL), occasionally associated with adverse effects (between the ERL and ERM) and frequently associated with adverse effects (above the ERM). No available data of sediment PAH content was available for the reference localities; however, these are situated in a relatively low populated area without any large sources of industrial pollution (Carballeira et al., 1997).

\section{Meiofauna}

A total of 14 major taxa, composed of 24625 individuals were identified in this study. The meiofauna collected at affected beaches was largely composed of copepods and nematodes, and copepods were the dominant taxon at 6 of the 9 impacted sites. However, at TRA1 copepods were co-dominant with turbellarians. Nematodes were the dominant taxa at 2 sites and at CAR2 the dominant taxa were gastrotrichs. Copepods, nematodes and turbellarians were present at all the studied sites, while ostracods were only absent at CAR1. The rest of the meiofaunal taxa occurred in small numbers and were less common. At the reference sites, the meiobenthic community was also dominated by copepods and nematodes.
Copepods were the dominant taxa at REF A and REF C, while nematodes were the most abundant taxa at REF B. Turbellarians, gastrotrichs, polychaetes and tardigrades were present at all the reference sites, while foraminiferans, ostracods and halacaroid mites were present at two of the three reference sites (Rubal, 2008; Veiga, 2008).

The mean values $\pm \mathrm{SD}$ of the total meiofauna density, total number of taxa and main taxon density at each site, including both the affected and reference sites, are represented in Figure 2. Mean values of the total meiofauna density ranged between $64 \pm 4$ individuals $10 \mathrm{~cm}^{-2}$ at BAR and $2100 \pm 480$ individuals $10 \mathrm{~cm}^{-2}$ at ROD1. One-way ANOVA analysis revealed significant differences in the total meiofauna density between sites $\left(\mathrm{F}_{11,24}=22.89, \mathrm{p}<0.001\right)$ (Fig. 2A). The affected sites EST, BAR and TRA1 were significantly different from the 3 reference sites due to their low total meiofauna density values. The number of taxa ranged from $4.00 \pm 1.00$ at BAR to $8.00 \pm 1.00$ at REF A. One-way ANOVA analysis revealed significant differences $\left(\mathrm{F}_{11,24}=4.98\right.$, $\mathrm{p}<0.001$ ) in the number of taxa between sites (Fig. 2B). Even when significant differences between sites were detected, none of the affected sites had significant differences compared to the reference sites. Turbellarian density ranged from $0.48 \pm 0.82$ individuals $10 \mathrm{~cm}^{-2}$ at MUI to $28 \pm 16$ individuals 10 $\mathrm{cm}^{-2}$ at TRA2. One-way ANOVA analysis revealed significant differences in the turbellarian density between sites $\left(\mathrm{F}_{11,24}=10.80, \mathrm{p}<0.001\right)$ (Fig. $\left.2 \mathrm{C}\right)$. From the 9 impacted sites only MUI showed significant differences with the 3 reference sites due to its low turbellarian density. Gastrotrich density varied from $0.33 \pm 0.58$ individuals $10 \mathrm{~cm}^{-2}$ at TRA1 to $143 \pm$ 193 at CAR2, and gastrotrichs were absent at BAR, ROD1, ROD2 and MUI. One-way ANOVA analysis revealed significant differences in the gastrotrich 

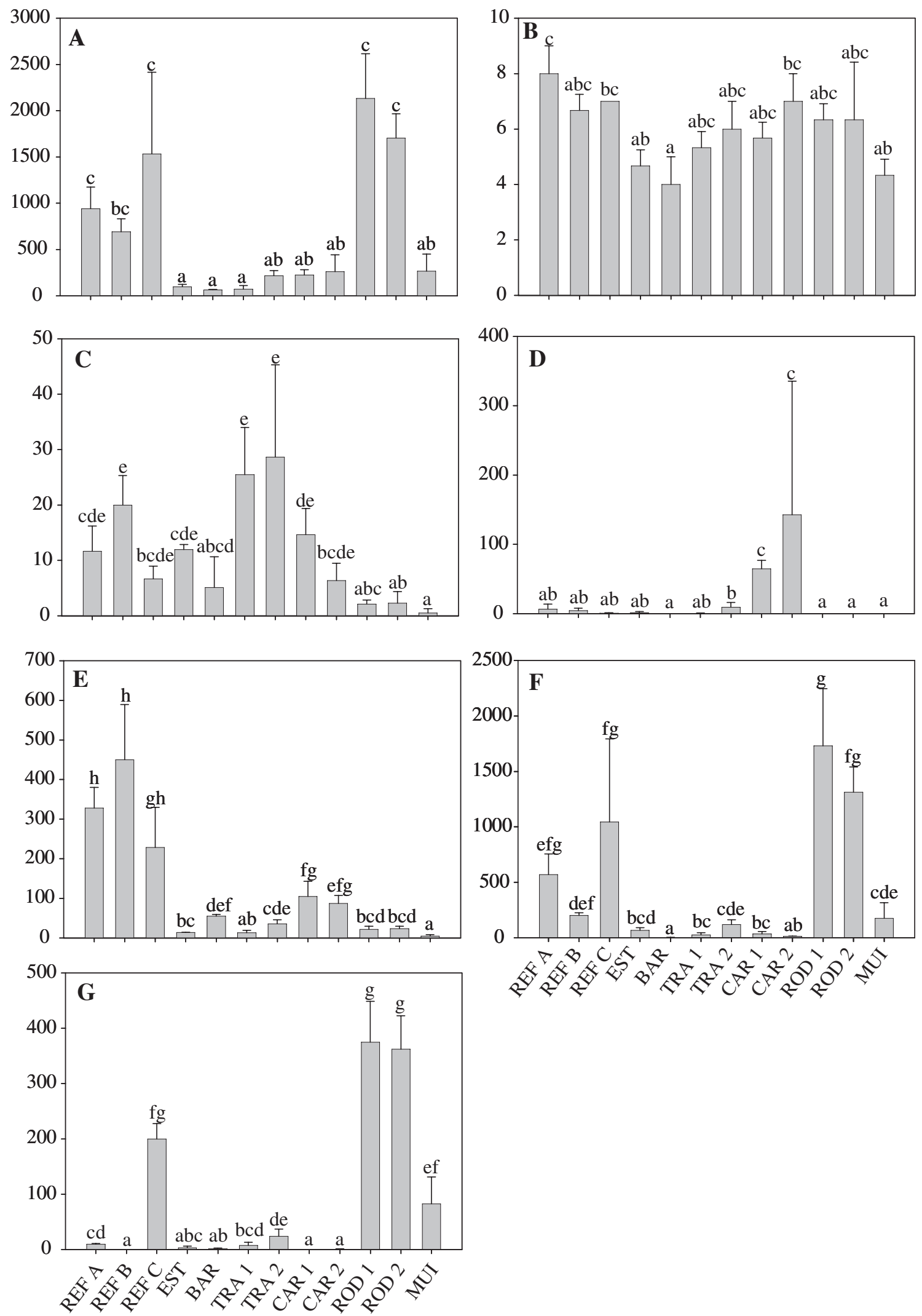

FIG. 2. - Mean \pm SD values of: total meiobenthic density (A), number of meiobenthic taxa (B), turbellarian density (C), gastrotrich density (D), nematode density (E), copepod density (F) and ostracod density (G). Units of the y axis are densities expressed in individuals $10 \mathrm{~cm}^{-2}$, except for $2 \mathrm{~B}$ where the $\mathrm{y}$ axis is the number of taxa. Different letters identify significant differences among sampling sites determined by the Tukey honestly significant difference multiple-comparison test $(p<0.05)$. Sites that do not share any letters have significant differences. 
TABLE 3. - Results of the hierarchical partitioning analysis. \%I indicates the percentage of the independent contribution to the explained variance by each PAH and environmental factor. Significant predictors are indicated by asterisks.

\begin{tabular}{|c|c|c|c|c|c|c|c|c|}
\hline \multirow[t]{2}{*}{ Taxa } & \multicolumn{2}{|c|}{ Dean } & \multicolumn{2}{|c|}{$\mathrm{W}$} & \multicolumn{2}{|c|}{ 1-2Dimethylnaphthalene } & \multicolumn{2}{|c|}{ 1-Methylphenanthrene } \\
\hline & Z. score & $\% \mathrm{I}$ & Z. score & $\% \mathrm{I}$ & Z. score & $\% \mathrm{I}$ & Z. score & $\% \mathrm{I}$ \\
\hline Turbellarians & 0.98 & 11.45 & 1.33 & 13.84 & 2.72 & $23.07 * *$ & 6.90 & $51.63 * * *$ \\
\hline Gastrotrichs & 8.18 & $59.35 * * *$ & 1.86 & $17.25^{*}$ & 0.65 & 9.80 & 1.28 & 13.60 \\
\hline Nematodes & 4.55 & $32.27 * * *$ & 0.54 & 7.94 & 5.76 & $39.93 * * *$ & 2.34 & $19.86 * *$ \\
\hline Copepods & 0.93 & 11.89 & 6.37 & $47.06 * * *$ & 1.92 & $19.20 *$ & 2.36 & $21.84 * *$ \\
\hline Ostracods & 4.34 & $30.60 * * *$ & 3.59 & $26.57 * * *$ & 2.39 & $18.03 * *$ & 3.56 & $24.80 * * *$ \\
\hline
\end{tabular}

$* p<0.05 ; * * p<0.01 ; * * * p<0.001$

density between sites $\left(\mathrm{F}_{11,24}=15.53, \mathrm{p}<0.001\right)$ (Fig. 2D). CAR1 and CAR2 were significantly different from the rest of the studied sites, both reference and impacted, due to their high gastrotrich density. Nematode density ranged from $4.8 \pm 3.2$ individuals $10 \mathrm{~cm}^{-2}$ at MUI to $450 \pm 140$ individuals $10 \mathrm{~cm}^{-2}$ at REFB. One-way ANOVA analysis revealed significant differences in the nematode density between sites $\left(\mathrm{F}_{11,24}=50.78, \mathrm{p}<0.001\right)$ (Fig. 2E). Apart from CAR1 and CAR2, with relevant nematode densities, all the affected sites showed significant differences with the reference sites. Copepod density (including nauplii) ranged between $1.5 \pm 1.5$ individuals $10 \mathrm{~cm}^{-2}$ at BAR and $1730 \pm 515$ individuals $10 \mathrm{~cm}^{-2}$ at ROD1. One-way ANOVA analysis revealed significant differences in copepod density between sites $\left(\mathrm{F}_{11,24}=29.17, \mathrm{p}<0.001\right)$ (Fig. $\left.2 \mathrm{~F}\right)$. Four affected sites, BAR, TRA1, CAR1 and CAR2, with the lowest copepod densities, showed significant differences with the reference ones. Ostracod density ranged from $0.48 \pm 0.82$ at CAR2 to $375 \pm 74$ individuals 10 $\mathrm{cm}^{-2}$ at ROD1, and were absent at REFB and CAR1. One-way ANOVA analysis revealed significant differences in the ostracod density between sites $\left(\mathrm{F}_{11,24}\right.$ $=60.60$, p $<0.001)$ (Fig. 2G). Even when significant

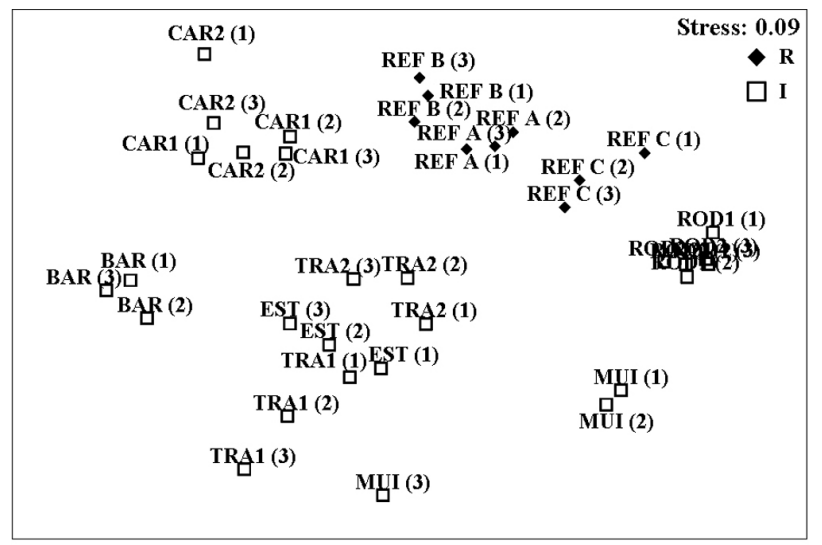

FIG. 3. - MDS plot, full diamonds represent reference sites (R) and empty squares represent impacted sites (I). differences between sites were detected, none of the impacted sites showed significant differences compared to the reference sites. The multidimensional scaling (MDS) ordination obtained from the meiofaunal taxon density is presented in Figure 3. The low stress level (0.09) indicates that an acceptable representation of the similarity in community structure was achieved (Clarke, 1993). The MDS ordination showed all the reference localities closely clustered. The affected localities ROD and CAR were placed in two different groups, slightly separated from the reference localities. All the other affected localities were clearly separated from the references. TRA, EST and a replica from MUI formed a single group while BAR and other replicas of MUI formed two individual groups.

The combination of 1,2-dimethylnaphthalene (C2-NAPH) and 1-methylphenanthrene (C-PHEN) was the only significant combination of sediment PAHs detected by the BVSTEP analysis $(r=0.718)$. The following BIOENV analysis performed with these two PAHs and environmental parameters, revealed two best parameter combinations: (CPHEN), Dean's parameter and Wc $(r=0.795)$ and (C2-NAPH), (C-PHEN), Dean's parameter and Wc $(r=0.786)$. These results show that both the environmental characteristics and the PAHs were relevant factors in structuring the meiobenthic community at impacted beaches.

Results of the Hp are shown in Table 3. Gastrotrichs were the only taxa that did not show any correlation with PAHs. Instead, Dean's parameter explained a high portion of their density variability. For the ostracods and copepods both C2-NAPH and C-PHEN and environmental variables showed a significant correlation. In these taxa the percentage of abundance explained by environmental parameters was slightly higher than the variability explained by PAHs. Nematode variance was mainly explained by C2-NAPH and C-PHEN, but Dean's parameter still 
explained a large percentage of its variability. Finally, only C2-NAPH and C-PHEN were significantly correlated with turbellarian density, and explain almost all of its variability.

\section{DISCUSSION}

After large spills most of the oil is accumulated in intertidal areas, where the amount of oil on the shoreline is generally orders of magnitude higher than in the subtidal zone (Lee and Page, 1997). However, exposed sandy beaches are habitats with strong hydrodynamics due to the high wave action and currents. Moreover, the easy access to these beaches usually allows effective cleaning activities. Therefore, recovery in these habitats is faster than in sheltered ones (Kingston, 2002). Despite the exposed nature of the studied beaches, six months after the Prestige spill, significant concentrations of PAHs were detected in the swash zone. At all the localities many of these PAHs had concentrations above the ERL or ERM. The observed incidence of negative effects when toxic concentration values are between the ERL and ERM is higher than 25\% (Long et al., 1995), while the incidence when toxic concentrations are above the ERM values are 75\% and occasionally $100 \%$. A review of numerical sediment quality guidelines by Long et al. (1998) found a significant increase in negative effects of toxics, with an increasing number of chemicals that exceed the ERL, and especially the ERM. Taking into account that at all the impacted localities of this study, 3 or more PAHs were above the ERL or ERM values six months after the Prestige spill, it can be expected that there is a high probability of negative effects on the meiobenthos.

Anthropogenic impacts are ideally assessed through a BACI (before-after, control-impact) design. However, it is not always possible to apply such a design, particularly in the case of accidental oil spills, which are impossible to predict and once they occur, background data are not available to assess the extent of the impact. In this situation, the only appropriate sampling design is an asymmetrical design. The asymmetrical "beyond BACI" designs described by Underwood (1994) can be modified and used to identify environmental impacts when only "after data" are available, by comparing the disturbed locations with multiple controls (Glasby, 1997). However, working at a higher taxonomic level, environmental variables have a less confounding effect and the impact is more visible (Warwick, 1993).

When the total meiobenthic and main taxon density is compared between impacted and reference beaches some effects that could be related to the spill were detected. Nematode abundance, with the exception of CAR1 and CAR2, was significantly lower at the affected sites. Even if some nematode species are commonly identified as pollution tolerant, the density and diversity of these taxa could be reduced by pollution events, as was recorded by Wormald (1976) and Beyrem and Aissa, (2000). Copepod abundance was significantly lower at four impacted sites (BAR, TRA1, CAR1 and CAR2). These taxa have proved to be very sensitive to acute toxicity during many oil spill events (Wormald, 1976; Ansari and Ingole, 2002; Veiga et al., 2009) and in laboratory experiments (Frithsen et al., 1985). Gastrotrich density was significantly higher at two affected localities (CAR1 and CAR2). Many authors have found that some species of gastrotrichs could reach high density values at polluted sites (Hummon et al., 1990; Evans et al., 1993). Total meiofauna density was significantly lower at affected sites EST, BAR and TRA1. These three sites showed similar values of total meiofauna density and number of taxa as polluted sites at exposed beaches during the acute phase of the spill, November and December 2002 (Veiga et al., 2007).

However, multivariate analyses have proven to be a more efficient method than univariate analyses for detecting environmental disturbances in benthic communities (Clarke, 1993). The spatial distribution of localities on the MDS plot seems to be determined by two main factors: beach morphodynamic state and the degree of impact of the spill. While the most reflective beaches (ROD, MUI and REFC) were placed on the right side of the MDS plot, intermediate beaches were on the left side. However, reference localities were clustered together while more affected localities (EST, BAR and TRA1), with communities similar to those recorded during the acute phase of the spill (Veiga et al., 2007), were clearly clustered separately from them. The MDS ordination showed a clear trend related to pollution; however, the differences found between the reference and affected beaches should be interpreted with caution. The high intrinsic variability of ecological systems makes identifying and interpreting humaninduced changes in natural populations a difficult 
task (Benedetti-Cecchi, 2001). In this work, reference localities could not be sampled simultaneously to the affected ones due to the extensive impact of the spill from Galicia to the Atlantic French coast. Therefore, data from localities sampled one year before were the best available reference data. The possible importance of inter-annual variation of sandy beach meiofauna on the studied coasts has not been analyzed, and could be a confounding factor in the interpretation of the previous results. In order to solve this limitation the relationship of meiofauna taxon abundance and community structure with sediment PAH content and environmental factors on affected sites was analyzed.

This analysis showed that $\mathrm{C} 2-\mathrm{NAPH}$ and C-PHEN played an important role both in community structure and taxon abundance, together with Dean's parameter and Wc. These two PAHs explained a large part of the main taxon density, except for gastrotrichs, demonstrating that the high density reached by this group at the affected sites of CAR1 and CAR2 could not be due to the spill effect. However, Dean's parameter and Wc played a more important role in explaining the abundance of ostracods and copepods than in other taxa, probably because of the high density of these taxa found on reflective beaches (ROD and MUI), which usually retain less water during low tide due to their slope and grain size. It should be noted that both the $\mathrm{C} 2$ NAPH and C-PHEN have been identified as two PAHs associated with the Prestige oil spill (Barata et al., 2005), and their toxic and narcotic effects on zooplankton copepods have been studied in laboratory tests (Barata et al., 2005; Calbet et al., 2007). These toxicological studies were performed with dissolved PAHs, so the LC50 and EC50 concentrations cannot be compared with the amount of these two PAHs in sediments due to the differences in units and bioavailability. However, large concentrations of these two PAHs were present at all impacted localities (Table 2). According to the results of Long et al. (1998) and Barata et al. (2005) mixtures of PAHs had additive effects, increasing the negative effects on fauna. Therefore, in addition to the effect of $\mathrm{C} 2$ NAPH and C-PHEN, all the PAHs in Table 2 could be responsible for the detected effects on meiofauna. The important role of PAHs in the density of the most abundant taxa and community structure is supported by the results of univariate and multivariate comparisons between affected and reference localities. In contrast, Rodríguez et al. (2007) did not find differences in occurrence of the major taxa and total meiofauna density between affected beaches and previous data. However, a more detailed study, using both uni- and multivariate methods is necessary to detect subtle disturbances, because the occurrence of major taxon and total meiofauna density would be significantly modified only by large pollution events (Warwick, 1993). It can therefore be concluded that six months after the Prestige oil spill, exposed sandy beaches still contained several PAHs in concentrations that have potentially negative effects on benthic fauna. Both univariate and multivariate analyses showed significant differences between affected and reference beaches. The relevant role of PAHs, especially C2-NAPH and C-PHEN, in the structure of the meiofauna community and main taxon abundance would corroborate that PAHs are responsible for differences between the affected and reference localities.

\section{ACKNOWLEDGEMENTS}

The authors would like to thank L. Rubal and L. Veiga for sampling assistance, F. Arenas, C. Heip and anonymous reviewers for comments and criticism on the manuscript and A. Marhadour for reviewing the final version of the manuscript. J. Freire (Universidade da Coruña) provided the data of sediment PAHs. M. Lastra (Universidade de Vigo) provided environmental data of the studied sites. This research was supported by the Ministerio de Ciencia y Tecnología (Programa Nacional: Acción urgente Prestige-Recursos Naturales).

\section{REFERENCES}

Ansari, Z.A. and B. Ingole. - 2002. Effect of an oil spill from $M$ $V$ Sea Transporter on intertidal meiofauna at Goa, India. Mar. Pollut. Bull., 44: 396-402.

Arenas, F., I. Sánchez, S.J. Hawkins and S. Jenkins. - 2006. The invasibility of marine algal assemblages: role of functional diversity and identity. Ecology, 87(11): 2851-2861.

Barata, C., A. Calbet, E. Saiz, L. Ortiz, and J.M. Bayona. - 2005. Predicting single and mixture toxicity of petrogenic polycyclic aromatic hydrocarbons to the copepod Oithona davisae. Environ. Toxicol. Chem., 24(11): 2992-2999.

Benedetti-Cecchi, L. - 2001. Beyond Baci: optimization of environmental sampling designs through monitoring and simulation. Ecol. Appl., 11(3): 783-799.

Beyrem, H. and P. Aissa. - 2000. Les nématodes libres, organismessentinelles de l'évolution des concentrations d'hycrocarbures dans la baie de Bizerte (Tunisie). Cah. Biol. Mar., 41: 329-342.

Bodin, P. - 1988. Results of ecological monitoring of three beaches polluted by the "Amoco Cadiz" oil spill: development of meiofauna from 1978 to 1984. Mar. Ecol. Prog. Ser., 42: 105-123.

Brown, A.C. and A. McLachlan. - 1990. Ecology of sandy shores. 
Elsevier, Amsterdam.

Buchanan, J.B. - 1984. Sediment analysis. In: N.A. Holme and A.D. McIntyre (eds.), Methods for the study of marine benthos, pp. 41-65. Blackwell, Oxford.

Calbet, A., E. Saiz, and C. Barata. - 2007. Lethal and sublethal effects of naphthalene and 1,2-dimethylnaphthalene on the marine copepod Paracartia grani. Mar. Biol., 151: 195-204.

Carballeira, A., E. Carral, X.M. Puente and R. Villares. - 1997. Estado de conservación de la costa de Galicia: nutrientes y metales pesados en sedimentos y organismos intermareales. Servicio de Publicaciones e Intercambio científico, Santiago de Compostela.

Clarke, K.R. - 1993. Non parametric multivariate analyses of changes in community structure. Aust. J. Ecol., 18: 117-43.

Clarke, K.R. and M. Ainsworth. - 1993. A method of linking multivariate community structure to environmental variables. Mar. Ecol. Prog. Ser., 92: 205-219.

Ellis, D. - 1985. Taxonomic sufficiency in pollution assessment. Mar. Pollut. Bull., 16(12): 459.

Evans, W., M.A. Todaro and W.D. Hummon. - 1993. Eutrophication and Gastrotrich diversity in the Northern Adriatic Sea. Mar. Pollut. Bull., 26(5): 268-272.

Fleeger, J.W. and G.T. Chandler. - 1983. Meiofauna responses to an experimental oil spill in a Louisiana salt marsh. Mar. Ecol. Prog. Ser., 11: 257-264.

Frithsen, J.B., R. Elmgren and D.T. Rudnick. - 1985. Responses of benthic meiofauna to long-term, low-level additions of No.2 fuel oil. Mar. Ecol. Prog. Ser., 23: 1-14.

Glasby, T.M. - 1997. Analysing data from post-impact studies using asymmetrical analyses of variance: A case study of epibiota on marinas. Aust. J. Ecol., 22: 448-459.

Herman, P.M.J. and C. Heip. - 1988. On the use of meiofauna in ecological monitoring: Who needs taxonomy? Mar. Pollut. Bull., 19(12): 665-668.

Hummon, W.D., M.A. Todaro, M. Balsamo and P. Tongiorgi. 1990. Effects of pollution on marine gastrotrichs in the northwestern Adriatic Sea. Mar. Pollut. Bull., 21(5): 241-243.

Junoy, J., C. Castellanos, J.M. Viéitez, M.R. de la Huz and M. Lastra. - 2005. The macroinfauna of the Galician sandy beaches (NW Spain) affected by the Prestige oil-spill. Mar. Pollut. Bull., 50: 526-536.

Kingston, P.F. - 2002. Long-term environmental impact of oil spills. Spill Sci. Technol. B., 7(1-2): 53-61.

Lee, K. and D.S. Page. - 1997. Petroleum hydrocarbons and their effects in subtidal regions after major oil spills. Mar. Pollut. Bull., 34(11): 928-940.

Long, E.R., L.J. Field and D.D. Macdonald. - 1998. Predicting toxicity in marine sediments with numerical sediment quality guidelines. Environ. Toxicol. Chem., 17(4): 714-727.

Long, E.R., D.D. Macdonald, S.S. Smith and F.D. Calder - 1995. Incidence of adverse biological effects within ranges of chemical concentrations in marine and estuarine sediments. Environ. Manage., 19(1): 81-97.

Lotufo, G.R. and J.W. Fleeger. - 1997. Effects of sediment-associ- ated phenanthrene on survival, development and reproduction of two species of meiobenthic copepods. Mar. Ecol. Prog. Ser., 151: 91-102.

Mac Nally, R. - 2000. Regression and model-building in conservation biology, biogeography and ecology: the distinction between-and reconciliation of-"predictive" and "explanatory" models. Biodivers. Conserv., 9: 655-671.

Moore, C.G. and B.J. Bett. - 1989. The use of meiofauna in marine pollution impact assessment. Zool. J. linn. Soc., 96: 263-280.

Pfannkuche, O. and H. Thiel. - 1988. Sample processing. In: R.P. Higgins and H. Thiel (eds.), Introduction to the study of meiofauna, pp. 134-145. Smithsonian Inst. Press, Washington.

Rodríguez, J.G., M. Incera, R. de la Huz, J. López and M. Lastra. 2007. Polycyclic aromatic hydrocarbons (PAHs), organic matter quality and meiofauna in Galician sandy beaches, 6 months after the Prestige oil-spill. Mar. Pollut. Bull., 54: 1031-1071.

Rubal, M. - 2008. La meiofauna intermareal de sustratos blandos de la ría de Foz (Galicia). Ph.D. thesis, Univ. Santiago de Compostela.

Suchanek, T.H. - 1993. Oil impacts on marine invertebrate populations and communities. Amer. Zool., 33(6): 510-523.

Underwood, A.J. - 1994. On beyond BACI: sampling designs that might reliably detect environmental disturbance. Ecol. Appl. 4(1): 3-15.

Veiga, P. - 2008. La meiofauna intermareal de sustratos blandos de la ría de O Barqueiro (Galicia). Ph.D. thesis, Univ. Santiago de Compostela.

Veiga, P., M. Rubal and C. Besteiro. - 2007. Estudio preliminar del efecto del fuel sobre la meiofauna de algunas playas gallegas, en los primeros días de la marea negra del Prestige. Nov. Act. Cient. Compostelana (Bioloxía), 16: 87-99.

Veiga, P., M. Rubal and C. Besteiro. - 2009. Shallow sublittoral meiofauna communities and sediment polycyclic aromatic hydrocarbons (PAHs) content on the Galician coast (NW Spain), six months after the Prestige oil spill. Mar. Pollut. Bull., 58: 581-588.

Walsh, C. and R. Mac Nally. - 2003. The hier.part package. Hierarchical partitioning. $R$ project for statistical computing. (http:// cran.r-project.org/).

Walsh, C., P.J. Papas, D. Crowther, P.T. Sim and J. Yoo. - 2004. Stormwater drainage pipes as a threat to a stream-dwelling amphipod of conservation significance, Austrogammarus australis, in southeastern Australia. Biodivers. Conserv., 13: 781-793.

Warwick, R.M. - 1993. Environmental impact studies on marine communities: Pragmatical considerations. Aust. J. Ecol., 18: 63-80.

Whitfield, J. - 2003. How to clean a beach. Nature, 422: 464-466

Wormald, A.P. - 1976. Effects of a spill of marine diesel oil on the meiofauna of a sandy beach at Picnic Bay, Hong Kong. Environ. Pollut., 11: 117-130.

Scient. ed.: C. Heip.

Received May 25, 2009. Accepted October 19, 2009.

Published online March 22, 2010. 